\title{
Perbandingan Metode Bootstrap, Jacknife Jiang Dan Area Specific Jacknife Pada Pendugaan Mean Square Error Model Beta-Bernoulli
}

\author{
Yesi Santika ${ }^{1,{ }^{*}}$, Widiarti $^{1}$, Fitriani $^{1}$, Mustofa Usman ${ }^{1}$ \\ ${ }^{1}$ Jurusan Matematika, FMIPA, Universitas Lampung \\ Jalan Prof Dr. Soemantri Brojonegoro no 1 Bandar Lampung 35145, Indonesia \\ *Email korespondensi: yesisantika1@gmail.com
}

\begin{abstract}
Abstrak
Pendugaan area kecil didefinisikan sebagai teknik statistika untuk menduga parameter subpopulasi yang ukuran sampelnya kecil. Salah satu metode dalam pendugaan parameter area kecil adalah metode Empirical Bayes (EB). Keakuratan penduga Empirical Bayes (EB) dapat diukur dengan mengevaluasi Mean Squared Error (MSE). Dalam penelitian ini akan dibandingkan 3 metode untuk menentukan MSE pada penduga EB model Beta-Bernoulli yaitu metode Bootstrap, Jackknife Jiang dan Area-spesific Jackknife. Kajian dilakukan secara empiris melalui simulasi dengan software $R$-studio versi 1.2.5033. Hasil simulasi pada beberapa jumlah area dan pasangan nilai parameter distribusi prior yaitu Beta menunjukkan adanya pengaruh ukuran sampel dan pasangan nilai parameter terhadap nilai Mean Square Error (MSE). Semakin besar jumlah area dan semakin kecil $\beta$ awal maka nilai MSE akan semakin kecil. Metode Area spesific Jackknife menghasilkan MSE terkecil pada jumlah area 100 dan nilai parameter Beta 0.1.
\end{abstract}

Kata kunci: Model Beta-Bernoulli, Mean Square Error (MSE), Bootstrap, Jackknife Jiang, Area spesific Jackknife.

\begin{abstract}
Small area estimation is defined as a statistical technique for estimating the parameters of a subpopulation with a small sample size. One method of estimating small area parameters is the Empirical Bayes (EB) method. The accuracy of the Empirical Bayes (EB) estimator can be measured by evaluating the Mean Squared Error (MSE). In this study, 3 methods to determine MSE in the EB estimator of the Beta-Bernoulli model will be compared, namely the Bootstrap, Jackknife Jiang and Area-specific Jackknife methods. The study is carried out empirically through simulation with $R$-studio software version 1.2.5033. The simulation results in a number of areas and pairs of prior distribution parameter values, namely Beta, show the effect of sample size and parameter value pairs on the Mean Square Error (MSE) value. The larger the number of areas and the smaller the initial $\beta$, the smaller the MSE value. Area specific Jackknife method produces the smallest MSE in the number of areas 100 and the Beta parameter value 0.1.
\end{abstract}

Keywords: Beta-Bernoulli Model, Mean Square Error (MSE), Bootstrap, Jackknife Jiang, Area-specific Jackknife

\section{Pendahuluan}

Pendugaan area kecil (small area estimation) merupakan suatu teknik statistika untuk menduga parameterparameter subpopulasi yang ukuran sampelnya kecil. Pendugaan area kecil didasarkan pada penerapan model rancangan penarikan sampel atau yang disebut pendugaan langsung. Pendugaan langsung pada area kecil akan memberikan presisi yang rendah karena ukuran sampel yang kecil sehingga diperoleh penduga yang takbias tetapi memiliki ragam yang besar [1]. Oleh karena itu, dikembangkan teknik pendugaan tak langsung yang dapat meningkatkan keefektifan ukuran sampel serta dapat menurunkan keragaman dugaan parameter.

Pendugaan pada metode EB didasarkan pada distribusi posterior untuk menduga parameter yang dapat diperoleh dengan beberapa cara yaitu salah satunya dengan metode momen. Informasi tambahan pada pendugaan area kecil dikenal dengan distribusi prior. Pada penelitian ini, distribusi prior yang digunakan adalah distribusi Beta, sedangkan distribusi sampel yang digunakan adalah distribusi Bernoulli. Distribusi sampel yang dipilih berasal dari keluarga eksponensial sehingga salah satu cara untuk menentukan prior adalah dengan menggunakan prior konjugat [2]. Penduga Bayes biasanya bersifat bias [2], maka dalam penelitian ini kualitas EB dievaluasi melalui kriteria mean square error (MSE). MSE adalah suatu besaran untuk mengukur keragaman pendugaan 
area kecil. Semakin kecil MSE maka penduga semakin akurat. Beberapa penelitian yang membahas pendugaan MSE pada pendugaan area kecil adalah dapat dilihat di dalam [1], [3], [4], [5], dan [6].

Beberapa metode resampling juga telah dikembangkan untuk memperoleh MSE pada pendugaan area kecil. Beberapa metode resampling yang sering digunakan adalah metode Bootstrap, Jackknife Jiang dan Area-spesific Jackknife yang memiliki metode yang berbeda. Konsep metode Bootstrap adalah suatu resampling atau pengambilan data sampel yang dilakukan secara berulang ulang, sehingga akan diketahui berapa besar tingkat kesalahannya (error) [7]. Berbeda dengan Bootstrap, konsep metode Jackknife adalah menghilangkan satu data dan mengulanginya sebanyak jumlah sampel data yang ada. Metode Jackknife lainnya adalah metode Areaspecific Jackknife. Metode ini menggunakan ragam dari sebaran posterior sebagai pendekatan bagi nilai dugaan MSE [1]. Berdasarkan hal tersebut, pada penelitian ini peneliti tertarik untuk membandingkan ketiga metode resampling yaitu metode Bootstrap, Jackknife Jiang dan Area-spesific Jackknife pada pendugaan MSE model Beta-Bernoulli.

\section{Metode Penelitian}

Dalam penelitian ini akan dilakukan evaluasi terhadap MSE secara empiris dengan menggunakan software $\mathrm{R}$-studio versi 1.2.5033. Kajian secara empiris dilakukan melalui simulasi dengan membandingkan tiga metode resampling, yaitu metode Bootstrap, Jackknife Jiang dan Area-spesific Jackknife. Pendugaan area kecil dilakukan dengan menggunakan model Beta-Bernoulli. Sebelum dilakukan evaluasi MSE, terlebih dahulu dilakukan pendugaan parameter dengan metode Empirical Bayes. Beberapa peneliti sebelumnya telah melakukan penelitian terkait pendugaan Empirical Bayes dengan metode resampling, salah satunya yaitu dimana metode resampling yang digunakan adalah metode Bootstrap dengan model Beta Bernoulli dan parameter yang dipilih adalah $\alpha$ dan $\frac{1}{\alpha}$ [6]. Pada penelitian ini metode resampling yang dibandingkan yaitu metode Bootstrap, Jackknife Jiang dan Area-spesific Jackknife dan model yang dipilih adalah Beta-Bernoulli dengan parameter yang diduga adalah $\beta$ dan $\alpha=1 / \beta$.

Tahap pertama diasumsikan bahwa $y_{i} \sim \operatorname{Bernoulli}\left(\theta_{i}\right)$ dan pada tahap kedua diasumsikan bahwa $\theta_{i} \sim$ Beta $(1 / \beta, \beta)$, dengan $y_{i}$ menyatakan kejadian sukses atau gagal pada area ke- $i, \theta_{i}$ adalah peluang keberhasilan suatu kasus pada area ke-i yang tidak diketahui dan $m$ menyatakan jumlah area, sedangkan $\beta$ merupakan parameter yang belum diketahui. Adapun langkah-langkah yang dilakukan pada penelitian ini adalah sebagai berikut :

a) Menentukan fungsi kepekatan akhir (posterior) dari sampel acak $y_{i} \sim \operatorname{Bernoulli}\left(\theta_{i}\right)$ dan prior $\theta_{i} \sim \operatorname{Beta}(1 / \beta, \beta)$ dengan persamaan sebagai berikut:

$$
f\left(\theta_{i} \mid y_{i}\right)=\frac{f\left(\theta_{i} ; y_{1}, \ldots, y_{m}\right)}{m\left(y_{1}, \ldots, y_{m}\right)}
$$

b) Menentukan penduga Empirical Bayes bagi dari model Beta-Bernoulli dengan persamaan berikut:

$$
\widehat{\theta}_{l}^{B}=E\left(\theta_{i} \mid y_{i}\right)
$$

c) Menentukan penduga $\beta$ dengan menggunakan metode momen berdasarkan fungsi kepekatan peluang marginal $y_{i}$.

d) Mengevaluasi MSE bagi penduga Empirical Bayes dengan metode Bootstrap, Jackknife Jiang dan Areaspesific Jackknife. berikut:

Pengevaluasian MSE dilakukan secara empiris melalui kajian simulasi dengan ulangan 1000 kali sebagai

1) Menetapkan nilai pasangan parameter awal dengan $\alpha=1 / \beta$ dan $\beta$ yaitu $(1 / 0.1,0.1),(1 / 0.2,0.2)$, $(1 / 0.3,0.3),(1 / 0.4,0.4),(1 / 0.5,0.5),(1 / 0.6,0.6),(1 / 0.7,0.7),(1 / 0.8,0.8)$ dan $(1 / 0.9,0.9)$.

2) Menetapkan jumlah area yaitu 30, 50, dan 100 sebagai representasi jumlah area yang berukuran kecil, sedang, dan besar.

3) Membangkitkan data $\theta_{i}$ dengan $\theta_{i} \sim \operatorname{Beta}(1 / \beta, \beta)$.

4) Membangkitkan data $y_{i}$ dengan $y_{i} \sim \operatorname{Bernoulli}\left(\theta_{i}\right)$.

5) Menghitung nilai dugaan bagi $\beta$ dengan metode momen.

6) Menghitung nilai dugaan bagi $\theta_{i}$ dengan metode Emprical Bayes $\left(\hat{\theta}_{i}^{E B}\right)$.

7) Menghitung $\operatorname{MSE}\left(\hat{\theta}_{i}^{E B}\right)$ dengan metode Bootstrap.

8) Menghitung $\operatorname{MSE}\left(\hat{\theta}_{i}^{E B}\right)$ dengan metode Jackknife Jiang.

9) Menghitung MSE $\left(\hat{\theta}_{i}^{E B}\right)$ dengan metode Areaspesific Jackknife

\section{Hasil dan Pembahasan}

Model dasar yang digunakan dalam penelitian ini adalah model berbasis area dua level. Tahap pertama diasumsikan bahwa $y_{i} \sim \operatorname{Bernoulli}\left(\theta_{i}\right)$ dan pada tahap kedua diasumsikan bahwa $\theta_{i} \sim \operatorname{Beta}(1 / \beta, \beta)$ sehingga fungsi kepekatan peluang distribusi prior dalam penelitian ini yaitu: 
dengan fungsi peluang sampel pada penelitian ini adalah:

$$
\pi\left(\theta_{i}\right)=\frac{\Gamma(1 / \beta+\beta)}{\Gamma(1 / \beta) \Gamma(\beta)} \theta_{i}^{1 / \beta-1}\left(1-\theta_{i}\right)^{\beta-1}
$$

$$
f\left(Y_{i}=y_{i} \mid \theta_{i}\right)=\theta_{i}^{y_{i}}\left(1-\theta_{i}\right)^{1-y_{i}}
$$

Oleh karena itu, diperoleh fungsi kepekatan peluang bersama Beta-Bernoulli yaitu:

$$
\begin{aligned}
f\left(\theta_{i} ; y_{i}\right) & =f\left(Y_{i}=y_{i} \mid \theta_{i}\right) \cdot \pi\left(\theta_{i}\right) \\
& =\theta_{i}^{y_{i}}\left(1-\theta_{i}\right)^{1-y_{i}} \cdot \frac{\Gamma(1 / \beta+\beta)}{\Gamma(1 / \beta) \Gamma(\beta)} \theta_{i}^{1 / \beta-1}\left(1-\theta_{i}\right)^{\beta-1} \\
& =\frac{\Gamma(1 / \beta+\beta)}{\Gamma(1 / \beta) \Gamma(\beta)} \theta_{i}^{y_{i}+1 / \beta-1}\left(1-\theta_{i}\right)^{1-y_{i}+\beta-1} \\
& =\frac{\Gamma(1 / \beta+\beta)}{\Gamma(1 / \beta) \Gamma(\beta)} \theta_{i}^{y_{i}+1 / \beta-1}\left(1-\theta_{i}\right)^{\beta-y_{i}}
\end{aligned}
$$

Fungsi kepekatan peluang marginal dari peubah acak Y adalah sebagai berikut

$$
\begin{aligned}
& m\left(y_{i}\right)=\int_{-\infty}^{\infty} f\left(\theta_{i} ; y_{i}\right) d \theta_{i} \\
& =\int_{0}^{1} \frac{\Gamma(1 / \beta+\beta)}{\Gamma(1 / \beta) \Gamma(\beta)} \theta_{i}^{1 / \beta+y_{i}-1}\left(1-\theta_{i}\right)^{\beta+y_{i}} d \theta_{i} \\
& =\frac{\Gamma(1 / \beta+\beta)}{\Gamma(1 / \beta) \Gamma(\beta)} \int_{0}^{1} \theta_{i}^{1 / \beta+y_{i}-1}\left(1-\theta_{i}\right)^{\beta+y_{i}} d \theta_{i} \\
& =\frac{\Gamma(1 / \beta+\beta)}{\Gamma(1 / \beta) \Gamma(\beta)} B\left(1 / \beta+y_{i}, \beta-y_{i}+1\right) \\
& =\frac{\Gamma(1 / \beta+\beta)}{\Gamma(1 / \beta) \Gamma(\beta)} \frac{\Gamma\left(1 / \beta+y_{i}\right) \Gamma\left(\beta-y_{i}+1\right)}{\Gamma(1 / \beta+\beta+1)}
\end{aligned}
$$

Dengan demikian, fungsi kepekatan peluang posterior model Beta-Bernoulli adalah:

$$
\begin{aligned}
f\left(\theta_{i} \mid y_{1}, \ldots, y_{m}\right)= & \frac{f\left(\theta_{i} ; y_{1}, . ., y_{m}\right)}{m\left(y_{1}, . . y_{m}\right)} \\
& =\frac{\frac{\Gamma(1 / \beta+\beta)}{\Gamma(1 / \beta) \Gamma(\beta)} \theta_{i}^{1 / \beta+y_{i}-1}\left(1-\theta_{i}\right)^{\beta-y_{i}}}{\Gamma(1 / \beta+\beta)} \frac{\Gamma\left(1 / \beta+y_{i}\right) \Gamma\left(\beta-y_{i}+1\right)}{\Gamma(1 / \beta+\beta+1)} \\
& =\frac{\Gamma(1 / \beta+\beta+1)}{\Gamma\left(1 / \beta+y_{i}\right) \Gamma\left(\beta-y_{i}+1\right)} \theta_{i}{ }^{1 / \beta+y_{i}-1}\left(1-\theta_{i}\right)^{\beta-y_{i}}
\end{aligned}
$$

Diketahui bahwa distribusi dari $\theta_{i}$ adalah $\operatorname{Beta}\left(1 / \beta+y_{i}, \beta-y_{i}+1\right)$, sehingga didapatkan penduga Bayes bagi $\theta_{i}$ yaitu:

$$
\begin{aligned}
\hat{\theta}_{i}^{B} & =E\left(\theta_{i} \mid y_{1}, \ldots, y_{m}\right) \\
& =\int_{0}^{1} \theta_{i} \cdot f\left(\theta_{i} \mid y_{i}\right) d \theta_{i} \\
& =\int_{0}^{1} \theta_{i} \frac{\Gamma(1 / \beta+\beta+1)}{\Gamma\left(1 / \beta+y_{i}\right) \Gamma\left(\beta-y_{i}+1\right)} \theta_{i}^{1 / \beta+y_{i}-1}\left(1-\theta_{i}\right)^{\beta-y_{i}} d \theta_{i} \\
& =\frac{\Gamma(1 / \beta+\beta+1)}{\Gamma\left(1 / \beta+y_{i}\right) \Gamma\left(\beta-y_{i}+1\right)} \int_{0}^{1} \theta_{i}{ }^{1 / \beta+y_{i}}\left(1-\theta_{i}\right)^{\beta-y_{i}} d \theta_{i}
\end{aligned}
$$




$$
\begin{aligned}
& =\frac{\Gamma(1 / \beta+\beta+n)}{\Gamma\left(1 / \beta+y_{i}\right) \Gamma\left(\beta-y_{i}+n\right)} B\left(1 / \beta+y_{\mathrm{i}}+1, \beta-\mathrm{y}_{\mathrm{i}}+1\right) \\
& =\frac{\Gamma(1 / \beta+\beta+1)}{\Gamma\left(1 / \beta+\mathrm{y}_{\mathrm{i}}\right)} \frac{\Gamma\left(1 / \beta+\mathrm{y}_{\mathrm{i}}+1\right)}{\Gamma(1 / \beta+\beta+2)} \\
& =\frac{(1 / \beta+\beta) !}{\left(1 / \beta+\mathrm{y}_{\mathrm{i}}-1\right) !} \frac{\left(1 / \beta+\mathrm{y}_{\mathrm{i}}\right) !}{(1 / \beta+\beta+1) !} \\
& =\frac{1 / \beta+\mathrm{y}_{\mathrm{i}}}{1 / \beta+\beta+1} \\
& =\frac{1+\mathrm{y}_{\mathrm{i}} \beta}{\beta^{2}+\beta+1} \quad,
\end{aligned}
$$

dengan $y_{i}$ adalah kejadian sukses atau gagal pada area ke-i dan $\theta_{i}$ adalah parameter dari distribusi Bernoulli. Bila penduga Bayes ini akan digunakan maka harus diketahui terlebih dahulu nilai parameter distribusi priornya. Selanjutnya, paramater distribusi prior akan diduga menggunakan metode momen. Oleh karena itu, diperoleh penduga Bayes empirik sebagai berikut:

$$
\hat{\theta}_{i}^{E B}=\frac{1+\mathrm{y}_{\mathrm{i}} \hat{\beta}}{\hat{\beta}^{2}+\hat{\beta}+1}
$$

Menurut Martinez [8], nilai ekspektasi dari distribusi Beta-Bernoulli adalah:

$$
\begin{aligned}
E\left(y_{i} \mid 1 / \beta, \beta\right) & =E\left[E\left(y_{i} \mid 1 / \beta, \beta\right)\right] \\
& =E\left(\theta_{i} \mid 1 / \beta, \beta\right) \\
& =\frac{1 / \beta}{1 / \beta+\beta},
\end{aligned}
$$

Untuk mendapatkan penduga bagi $\beta$ dengan metode momen, yaitu dengan menyamakan momen ke-1 sebagai berikut

Persamaan terakhir memberikan

$$
E(y)=\frac{1 / \beta}{1 / \beta+\beta}=m_{1}=\frac{\sum y_{i}}{n}=\bar{y}
$$

$$
\beta=\frac{1-\bar{y}}{\bar{y}} \text { atau } \beta=-\frac{1-\bar{y}}{\bar{y}}
$$

Karena $y_{i}$ berdistribusi Bernoulli dengan batas nilai parameter yaitu 0 sampai 1 atau bernilai positif, dengan demikian nilai $\hat{\beta}$ yang memenuhi adalah

$$
\hat{\beta}=\frac{1-\bar{y}}{\bar{y}}
$$

Pembangkitan data dalam simulasi dilakukan dengan menggunakan softwere R-studio versi 1.2.5033. Diasumsikan data berdistribusi Beta-Bernoulli yaitu $y_{i} \sim \operatorname{Bernoulli}\left(\theta_{i}\right)$ dengan $\theta_{i} \sim \operatorname{Beta}(1 / \beta, \beta)$. Simulasi dilakukan untuk melihat karakteristik penduga yang dihasilkan metode Empirical Bayes secara empiris. Selanjutnya data dibangkitkan dengan jumlah area yaitu 30, 50, dan 100 sebagai representasi jumlah area yang berukuran kecil, sedang, dan besar. Representasi jumlah area yang berbeda-beda bertujuan untuk melihat pengaruh jumlah area terhadap nilai bias dan MSE pada masing-masing metode Bootstrap, Jackknife Jiang dan Area-spesific Jackknife. Ukuran resampling mengikuti jumlah areanya. Dalam penelitian ini, nilai $\beta$ awal yang digunakan adalah 0.1, 0.2, 0.3, 0.4, 0.5, 0.6, 0.7, 0.8 dan 0.9 dikarenakan model yang dipilih adalah Beta Bernoulli dimana parameter $\beta$ harus bernilai positif. Nilai $\beta$ awal yang berbeda digunakan untuk mengevaluasi nilai dugaan parameter dan MSE. Gambar 1 merupakan grafik fungsi kepekatan peluang (fkp) distribusi Beta pada beberapa nilai $\beta$ yang telah ditentukan sebelumnya. 


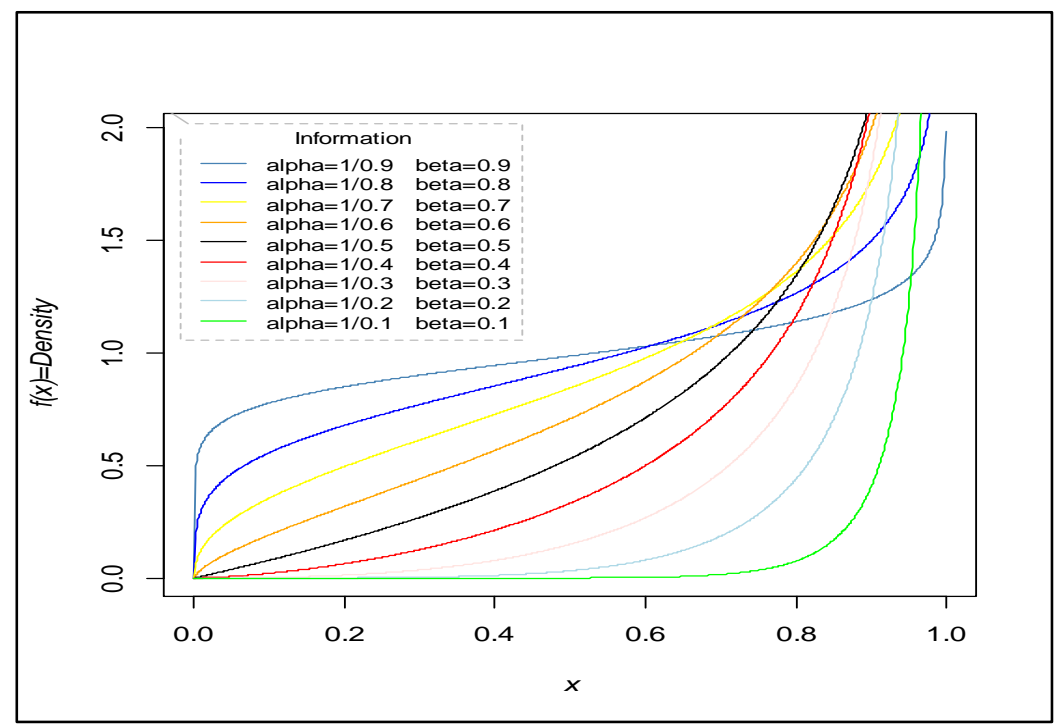

\section{Gambar 1. Grafik fungsi kepekatan peluang distribusi Beta pada beberapa nilai $\beta$.}

Berdasarkan Gambar 1, semakin besar nilai $\beta$ maka bentuk grafik fkp akan membentuk puncak dan semakin ke kanan akan melandai kemudian terus naik ketika mendekati nilai $\mathrm{x}=1$. Sedangkan ketika nilai $\beta$ awal semakin kecil maka bentuk awal grafik akan landai dan semakin ke kanan akan memuncak ketika nilai $\mathrm{x}=1$. Evaluasi nilai Mean Square Error dilakukan melalui simulasi dengan menggunakan nilai $\beta$ awal dan jumlah area 30, 50, dan 100.

Tabel 1. Hasil Kajian Simulasi Nilai Bias, MSE Bootstrap, MSE Jackknife Jiang dan MSE Area-spesific Jackknife untuk Jumlah Area 30

\begin{tabular}{|c|c|c|c|c|c|c|}
\hline \multirow[b]{2}{*}{$\beta$ awal } & \multirow{2}{*}{\multicolumn{2}{|c|}{$\begin{array}{l}\text { Ulangan } \\
\text { Bootstrap }\end{array}$}} & \multirow[b]{2}{*}{ Bias } & \multicolumn{3}{|c|}{ MSE } \\
\hline & & & & Bootstrap & $\begin{array}{c}\text { Jackknife } \\
\text { Jiang }\end{array}$ & $\begin{array}{c}\text { Area-spesific } \\
\text { Jackknife }\end{array}$ \\
\hline \multirow{3}{*}{0.1} & 0.011457 & 25 & 1.976626 & 0.003719 & 0.003269 & 0.001866 \\
\hline & 0.011187 & 50 & 1.977172 & 0.003919 & 0.004601 & 0.001882 \\
\hline & 0.010885 & 100 & 1.977801 & 0.003461 & 0.00339 & 0.00153 \\
\hline \multirow{3}{*}{0.2} & 0.040784 & 25 & 1.916178 & 0.023923 & 0.024198 & 0.0218 \\
\hline & 0.043028 & 50 & 1.911518 & 0.026937 & 0.026473 & 0.024378 \\
\hline & 0.041522 & 100 & 1.914602 & 0.024998 & 0.024235 & 0.023664 \\
\hline \multirow{3}{*}{0.3} & 0.092467 & 25 & 1.808369 & 0.105034 & 0.106478 & 0.139086 \\
\hline & 0.094266 & 50 & 1.804505 & 0.104042 & 0.090152 & 0.126845 \\
\hline & 0.094455 & 100 & 1.804172 & 0.104268 & 0.099996 & 0.131325 \\
\hline \multirow{3}{*}{0.4} & 0.164483 & 25 & 1.658774 & 0.274126 & 0.268436 & 0.397962 \\
\hline & 0.163116 & 50 & 1.661728 & 0.271507 & 0.255597 & 0.387557 \\
\hline & 0.164797 & 100 & 1.658134 & 0.276188 & 0.270167 & 0.397149 \\
\hline \multirow{3}{*}{0.5} & 0.268675 & 25 & 1.452842 & 0.621399 & 0.634073 & 1.027054 \\
\hline & 0.265525 & 50 & 1.458707 & 0.608426 & 0.608428 & 0.993094 \\
\hline & 0.25941 & 100 & 1.470247 & 0.591154 & 0.590432 & 0.945636 \\
\hline \multirow{3}{*}{0.6} & 0.37938 & 25 & 1.255504 & 1.000985 & 0.986591 & 1.692819 \\
\hline & 0.383704 & 50 & 1.247979 & 1.019833 & 1.020034 & 1.755416 \\
\hline & 0.375414 & 100 & 1.263828 & 0.989344 & 0.936683 & 1.639071 \\
\hline \multirow{2}{*}{0.7} & 0.515358 & 25 & 1.047309 & 1.412114 & 1.365259 & 2.41996 \\
\hline & 0.531571 & 50 & 1.024498 & 1.449048 & 1.428153 & 2.527512 \\
\hline
\end{tabular}




\begin{tabular}{clcclll} 
& 0.523321 & 100 & 1.036888 & 1.423048 & 1.388305 & 2.456662 \\
& 0.67631 & 25 & 0.850406 & 1.739117 & 1.706658 & 3.066714 \\
0.8 & 0.668324 & 50 & 0.857357 & 1.72975 & 1.749004 & 3.098047 \\
& 0.679121 & 100 & 0.844318 & 1.75338 & 1.725684 & 3.083495 \\
\multirow{3}{*}{0.9} & 0.878981 & 25 & 0.665416 & 1.937319 & 1.935495 & 3.501533 \\
& 0.862589 & 50 & 0.676242 & 1.937325 & 1.88897 & 3.455382 \\
& 0.879294 & 100 & 0.666073 & 1.937337 & 1.890061 & 3.445968 \\
\hline
\end{tabular}

Berdasarkan Tabel 1, nilai Mean Square Error (MSE) pada area 30 semakin kecil dengan $\beta$ awal yang semakin kecil. Berdasarkan Tabel 1, nilai MSE terkecil adalah 0.00153 dengan menggunakan metode Areaspesific Jackknife pada $\beta$ awal 0.1. Nilai MSE metode Bootstrap, metode Jackknife Jiang dan metode Areaspesific Jackknife berdasarkan Tabel 1 juga disajikan dalam bentuk grafik sebagai berikut.

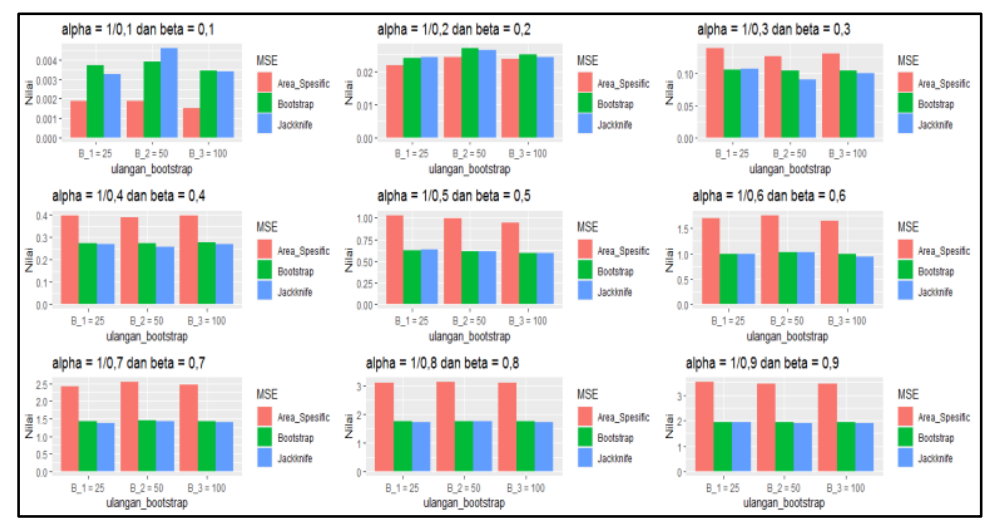

\section{Gambar 2. Grafik MSE Metode Bootstrap, Jackknife Jiang dan Area-spesific Jackknife untuk Jumlah Area 30}

Berdasarkan Gambar 2, grafik nilai MSE metode Bootstrap, metode Jackknife Jiang dan metode Areaspesific Jackknife pada jumlah area 30 naik dengan semakin besarnya nilai $\beta$ awal. Pada grafik yang disajikan, nilai MSE metode Area-spesific Jackknife lebih besar dari MSE metode Bootstrap dan metode Jackknife Jiang pada nilai $\beta$ awal $0.3,0.4,0.5,0.6,0.7,0.8$ dan 0.9 . Nilai MSE paling kecil yaitu 0.00153 dengan $\beta$ awal 0.1 pada metode Area-spesific Jackknife.

Tabel 2. Hasil Kajian Simulasi Nilai Bias, MSE Bootstrap, MSE Jackknife Jiang dan MSE Area-spesific Jackknife untuk Jumlah Area 50

\begin{tabular}{|c|c|c|c|c|c|c|}
\hline \multirow[b]{2}{*}{$\beta$ awal } & \multirow[b]{2}{*}{$\overline{\hat{\beta}}$} & \multirow{2}{*}{$\begin{array}{l}\text { Ulangan } \\
\text { Bootstrap }\end{array}$} & \multirow[b]{2}{*}{ Bias } & \multicolumn{3}{|c|}{ MSE } \\
\hline & & & & Bootstrap & $\begin{array}{c}\text { Jackknife } \\
\text { Jiang }\end{array}$ & $\begin{array}{c}\text { Areaspesific } \\
\text { Jackknife }\end{array}$ \\
\hline \multirow{3}{*}{0.1} & 0.010638 & 25 & 1.978416 & 0.002675 & 0.002328 & 0.001498 \\
\hline & 0.010644 & 50 & 1.978414 & 0.002389 & 0.002352 & 0.00108 \\
\hline & 0.009731 & 100 & 1.980269 & 0.00217 & 0.002624 & 0.000982 \\
\hline \multirow{3}{*}{0.2} & 0.039027 & 25 & 1.920125 & 0.020323 & 0.021093 & 0.022036 \\
\hline & 0.041512 & 50 & 1.914898 & 0.025425 & 0.027235 & 0.028357 \\
\hline & 0.040294 & 100 & 1.917454 & 0.023052 & 0.023035 & 0.024471 \\
\hline \multirow{3}{*}{0.3} & 0.092526 & 25 & 1.808317 & 0.114152 & 0.113877 & 0.162234 \\
\hline & 0.0918 & 50 & 1.809818 & 0.114691 & 0.1183 & 0.1624 \\
\hline & 0.092432 & 100 & 1.808488 & 0.116415 & 0.116958 & 0.165575 \\
\hline
\end{tabular}




\begin{tabular}{llcllll} 
& 0.167445 & 25 & 1.651747 & 0.380648 & 0.365116 & 0.60963 \\
0.4 & 0.16301 & 50 & 1.660754 & 0.356511 & 0.35276 & 0.582384 \\
& 0.167453 & 100 & 1.651559 & 0.375259 & 0.370858 & 0.604945 \\
& 0.253306 & 25 & 1.478695 & 0.808233 & 0.789147 & 1.384423 \\
0.5 & 0.25441 & 50 & 1.475777 & 0.809643 & 0.78726 & 1.392506 \\
& 0.259828 & 100 & 1.465207 & 0.841762 & 0.8214 & 1.439954 \\
& 0.373185 & 25 & 1.255176 & 1.476848 & 1.480228 & 2.644303 \\
0.6 & 0.363097 & 50 & 1.273091 & 1.416203 & 1.40073 & 2.518125 \\
& 0.372426 & 100 & 1.258268 & 1.464646 & 1.446129 & 2.60657 \\
& 0.500982 & 25 & 1.053252 & 2.102123 & 2.07425 & 3.858292 \\
0.7 & 0.506991 & 50 & 1.042564 & 2.142211 & 2.094656 & 3.928154 \\
& 0.497997 & 100 & 1.056177 & 2.099224 & 2.087493 & 3.833937 \\
& 0.667668 & 25 & 0.834586 & 2.715244 & 2.650342 & 4.992425 \\
0.8 & 0.656273 & 50 & 0.849601 & 2.672439 & 2.635018 & 4.922236 \\
& 0.663891 & 100 & 0.842293 & 2.686675 & 2.624352 & 4.954015 \\
& 0.832799 & 25 & 0.672264 & 3.021521 & 2.971383 & 5.613752 \\
0.9 & 0.855616 & 50 & 0.655477 & 3.039609 & 3.055772 & 5.711802 \\
& 0.840805 & 100 & 0.665218 & 3.035497 & 2.997924 & 5.651055 \\
\hline
\end{tabular}

Berdasarkan Tabel 2, nilai Mean Square Error (MSE) pada area 50 semakin kecil dengan $\beta$ awal yang semakin kecil. Berdasarkan Tabel 2, nilai MSE terkecil adalah 0.001498 dengan menggunakan metode Areaspesific Jackknife pada $\beta$ awal 0.1. Nilai MSE metode Bootstrap, metode Jackknife Jiang dan metode Areaspesific Jackknife berdasarkan Tabel 2 juga disajikan dalam bentuk grafik sebagai berikut.

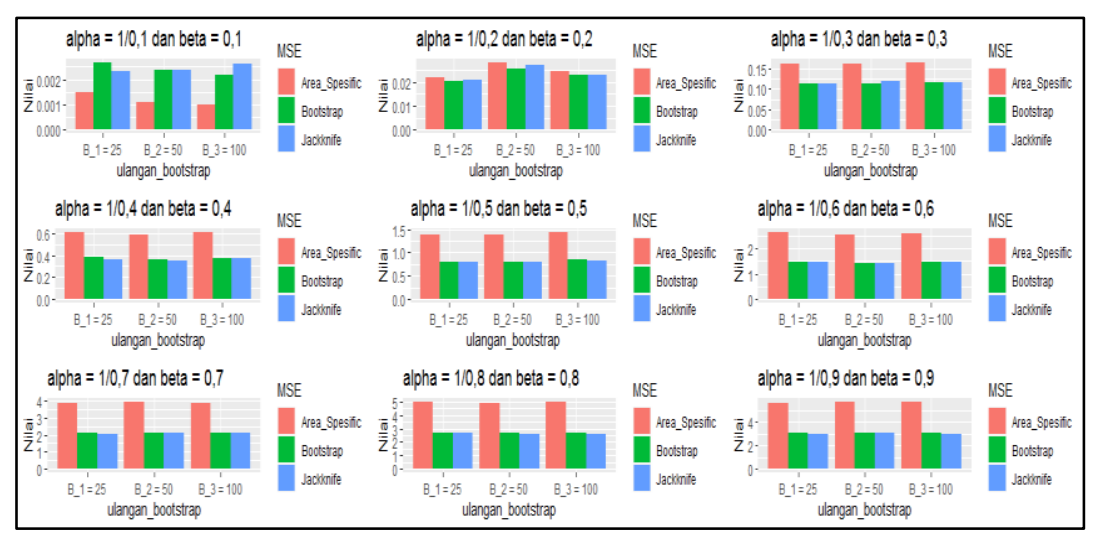

Gambar 3. Grafik MSE Metode Bootstrap, Jackknife Jiang dan Area-spesific Jackknife untuk Jumlah Area 50.

Berdasarkan Gambar 3, grafik nilai MSE metode Bootstrap, metode Jackknife Jiang dan metode Areaspesific Jackknife pada jumlah area 50 naik dengan semakin besarnya nilai $\beta$ awal. Pada grafik yang disajikan, nilai MSE metode Area-spesific Jackknife lebih besar dari MSE metode Bootstrap dan metode Jackknife Jiang pada nilai $\beta$ awal $0.2,0.3,0.4,0.5,0.6,0.7,0.8$ dan 0.9 . Nilai MSE paling kecil yaitu 0.000982 dengan $\beta$ awal 0.1 pada metode Area-spesific Jackknife. 
Tabel 3. Hasil Kajian Simulasi Nilai Bias, MSE Bootstrap, MSE Jackknife Jiang dan MSE Area-spesific Jackknife untuk Jumlah Area 100

\begin{tabular}{|c|c|c|c|c|c|c|}
\hline \multirow[b]{2}{*}{$\beta$ awal } & \multirow[b]{2}{*}{$\overline{\hat{\beta}}$} & \multirow{2}{*}{$\begin{array}{l}\text { Ulangan } \\
\text { Bootstrap }\end{array}$} & \multirow[b]{2}{*}{ Bias } & \multicolumn{3}{|c|}{ MSE } \\
\hline & & & & Bootstrap & $\begin{array}{c}\text { Jackknife } \\
\text { Jiang }\end{array}$ & $\begin{array}{c}\text { Areaspesific } \\
\text { Jackknife }\end{array}$ \\
\hline \multirow{3}{*}{0.1} & 0.009563 & 25 & 1.980701 & 0.001509 & 0.001532 & 0.000918 \\
\hline & 0.010303 & 50 & 1.979201 & 0.001703 & 0.001661 & 0.001133 \\
\hline & 0.009907 & 100 & 1.980001 & 0.001663 & 0.001521 & 0.001197 \\
\hline \multirow{3}{*}{0.2} & 0.040489 & 25 & 1.917318 & 0.025846 & 0.025185 & 0.035247 \\
\hline & 0.040974 & 50 & 1.916324 & 0.025826 & 0.027776 & 0.03373 \\
\hline & 0.041431 & 100 & 1.915335 & 0.028351 & 0.027959 & 0.03867 \\
\hline \multirow{3}{*}{0.3} & 0.090886 & 25 & 1.811913 & 0.161327 & 0.157062 & 0.263899 \\
\hline & 0.090913 & 50 & 1.81185 & 0.161879 & 0.167027 & 0.259415 \\
\hline & 0.089404 & 100 & 1.81504 & 0.154434 & 0.150431 & 0.248763 \\
\hline \multirow{3}{*}{0.4} & 0.162346 & 25 & 1.661531 & 0.580743 & 0.569833 & 1.027339 \\
\hline & 0.160056 & 50 & 1.666289 & 0.561399 & 0.557856 & 0.978824 \\
\hline & 0.163214 & 100 & 1.659713 & 0.586365 & 0.570971 & 1.030552 \\
\hline \multirow{3}{*}{0.5} & 0.257243 & 25 & 1.467258 & 1.440468 & 1.409317 & 2.650514 \\
\hline & 0.251685 & 50 & 1.478443 & 1.38294 & 1.370198 & 2.544677 \\
\hline & 0.25455 & 100 & 1.472676 & 1.412916 & 1.411701 & 2.589673 \\
\hline \multirow{3}{*}{0.6} & 0.363507 & 25 & 1.265678 & 2.575718 & 2.568867 & 4.846365 \\
\hline & 0.36544 & 50 & 1.262849 & 2.593926 & 2.574985 & 4.88833 \\
\hline & 0.367329 & 100 & 1.259624 & 2.620382 & 2.627985 & 4.916426 \\
\hline \multirow{3}{*}{0.7} & 0.496362 & 25 & 1.045814 & 3.908339 & 3.87264 & 7.412044 \\
\hline & 0.494306 & 50 & 1.048893 & 3.891269 & 3.894536 & 7.383686 \\
\hline & 0.502846 & 100 & 1.036773 & 3.960346 & 3.976438 & 7.526564 \\
\hline \multirow{3}{*}{0.8} & 0.653393 & 25 & 0.836472 & 5.031467 & 5.053086 & 9.690615 \\
\hline & 0.649791 & 50 & 0.838535 & 5.029047 & 4.979099 & 9.674604 \\
\hline & 0.645672 & 100 & 0.844018 & 5.003256 & 5.011626 & 9.588197 \\
\hline \multirow{3}{*}{0.9} & 0.831391 & 25 & 0.652866 & 5.724565 & 5.746983 & 11.06562 \\
\hline & 0.826371 & 50 & 0.6566 & 5.72423 & 5.693885 & 11.01749 \\
\hline & 0.824842 & 100 & 0.65824 & 5.720635 & 5.659312 & 10.97668 \\
\hline
\end{tabular}

Berdasarkan Tabel 3, nilai Mean Square Error (MSE) pada area 100 semakin kecil dengan $\beta$ awal yang semakin kecil. Berdasarkan Tabel 3, nilai MSE terkecil adalah 0.000918 dengan menggunakan metode Areaspesific Jackknife pada $\beta$ awal 0.1. Nilai MSE metode Bootstrap, metode Jackknife Jiang dan metode Areaspesific Jackknife berdasarkan Tabel 3 juga disajikan dalam bentuk grafik sebagai berikut. 


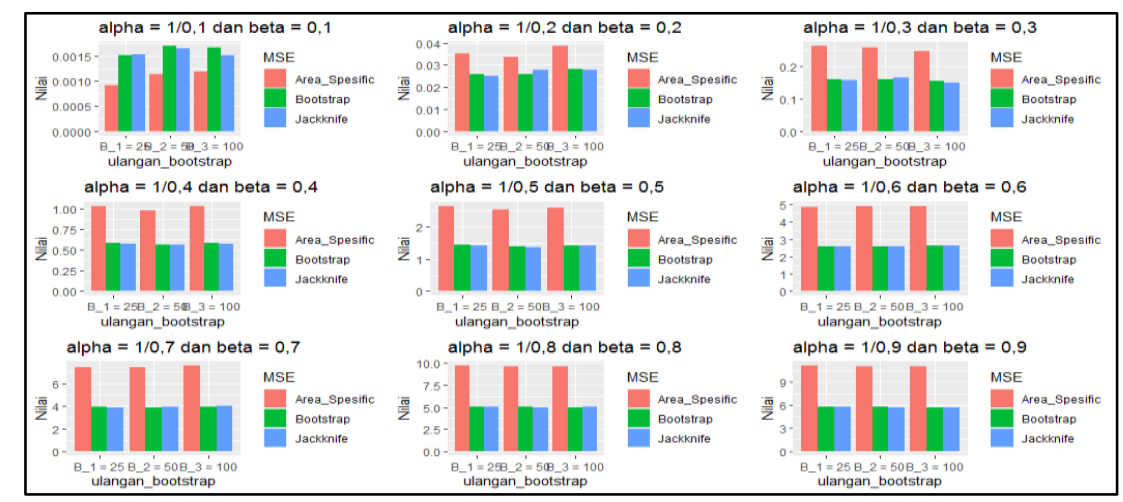

\section{Gambar 4. Grafik MSE Metode Bootstrap, Jackknife Jiang dan Area-spesific Jackknife untuk Jumlah Area 100.}

Berdasarkan Gambar 4, grafik nilai MSE metode Bootstrap, metode Jackknife Jiang dan metode Areaspesific Jackknife pada jumlah area 100 naik dengan semakin besarnya nilai $\beta$ awal. Pada grafik yang disajikan, nilai MSE metode Area-spesific Jackknife lebih besar dari MSE metode Bootstrap dan metode Jackknife Jiang pada nilai $\beta$ awal $0.2,0.3,0.4,0.5,0.6,0.7,0.8$ dan 0.9 . Nilai MSE paling kecil yaitu 0.000918 dengan $\beta$ awal 0.1 pada metode Area-spesific Jackknife.

Berdasarkan Tabel 1, 2 dan 3, metode Area-spesific Jackknife menghasilkan nilai MSE yang lebih kecil dibandingkan dengan MSE pada metode Bootstrap dan metode Jackknife Jiang. Berdasarkan Gambar 2, 3 dan 4, nilai Mean Square Error (MSE) semakin kecil dengan semakin besarnya jumlah area dan $\beta$ awal yang semakin kecil. Nilai MSE terkecil adalah 0.000918 yang dapat dilihat pada Tabel 3`dengan $\beta$ awal 0.1 dan jumlah area sebanyak 100. $\beta$ awal 0.1 merupakan nilai $\beta$ awal terkecil dan mempunyai selisih paling kecil dengan nilai $\overline{\hat{\beta}}$, sedangkan jumlah area 100 adalah jumlah area terbesar yang dipilih. Pada simulasi yang telah dilakukan dengan menggunakan $\beta$ awal 0.1 dan jumlah area sebanyak 100 area diperoleh penduga Bayes empirik $\left(\hat{\theta}_{i}^{E B}\right)$ sebesar 0.999639 .

\section{Kesimpulan}

Pada artikel ini telah dikaji pendugaan parameter subpopulasi yang ukuran sampelnya kecil. Dengan menggunakan metode Empirical Bayes (EB). Keakuratan penduga metode EB diukur dengan mengevaluasi Mean Squared Error (MSE). Dalam penelitian ini telah dibandingkan 3 metode untuk menentukan MSE pada penduga EB model Beta-Bernoulli yaitu metode Bootstrap, Jackknife Jiang dan Area-spesific Jackknife. Kajian dilakukan secara empiris melalui simulasi dengan software R-studio versi 1.2.5033. Hasil simulasi pada beberapa jumlah area dan pasangan nilai parameter distribusi prior yaitu Beta menunjukkan adanya pengaruh ukuran sampel dan pasangan nilai parameter terhadap nilai Mean Square Error (MSE). Semakin besar jumlah area dan semakin kecil $\beta$ awal maka nilai MSE akan semakin kecil. Metode Area spesific Jackknife menghasilkan MSE terkecil pada jumlah area 100 dan nilai parameter Beta 0.1 .

\section{Daftar Pustaka:}

[1] Rao, J.N.K and Molina, I. 2015. Small Area Estimation Second Edition. John Willey and Sons, Inc., New Jersey.

[2] Bolstad, W.M. 2007. Introduction to Bayesian Statistics. Ed ke-2. John Wiley \& Sons Inc.,America.

[3] Chen S. 2001. Empirical Best Prediction and Hierarchical Bayes Methods in Small Area Estimation. [Disertation]. Nebraska: The Graduate College, University of Nebraska.

[4] Jiang J., Lahiri P.,dan Wan S.M. 2002. A Unified Jackknife Theory for Empirical Best Prediction with M-estimation. The Annals of Statistics, 30(6):1782-1810.

[5] Chen S. dan Lahiri P. 2008. On Mean Squared Prediction Error Estimation in Small Area Estimation Problems. Communications in Statistic, 37:1792-1798.

[6] Widiarti, Adityawati, N. and Nusyirwan. 2019. Bootstrap Method in Estimation of Mean Squared Error of Beta-Bernoulli Model. Journal of Physics: Conference Series, 1338

[7] Efron, B. dan Tibshirani, R.J. 1993. An Introduction to the Bootstrap. Chapman and Hall, New York.

[8] Martinez, E.Z., Achcar, J.A., and Aragon, D.C. 2015. Paramater Estimation of The Beta-Binomial Distribution: An Application Using the SAS Software. Cienciae Natural, 37 (4):12-19. 